\title{
Universal values as a barrier to the effectiveness of global citizenship education: A multimodal critical discourse analysis
}

\author{
Jenny Hatley* - University of Worcester, UK
}

\begin{abstract}
The United Nations Educational, Scientific and Cultural Organization's (UNESCO) approach to global citizenship education (GCE) includes a set of values termed 'universal values'. These social ideals include peace, justice and sustainability, and are normatively considered a common good. A multimodal critical discourse analysis of universal values within key UNESCO texts reveals that rather than moving societies towards genuine mutual human well-being, a central theme of GCE, universal values are counterproductive to the achievement of GCE. To enable GCE to achieve its aims, UNESCO needs to incorporate a diverse concept of values that allows for motivations and actions towards global citizenship more relevant to local contexts.
\end{abstract}

Keywords: global citizenship education; multimodal critical discourse analysis; universal values; UNESCO; sustainable development goals; world values survey

\section{Introduction}

Target 4.7 of the United Nations Sustainable Development Goals (SDGs) promotes global citizenship education (GCE) as a vehicle to develop the skills, values and attitudes of learners so that they may work towards the resolution of the interconnected challenges facing the world today. Concentrating on the United Nations Educational, Scientific and Cultural Organization's (UNESCO) approach to GCE, this article draws on a multimodal critical discourse analysis of eight UNESCO documents that are central to the organization's approach. Focusing on the position of 'values' within the texts, this article examines the influence that UNESCO's 'universal values' have within GCE, and asks whether UNESCO's GCE can be effective in achieving its aims.

I argue that the approach taken to universal values within the texts contributes to socializing learners towards UNESCO's agenda at the expense of values and forms of global citizenship more relevant to local contexts. Further, I argue that universal values potentially cannot achieve their aims within GCE because they are abstract and disconnected from social reality. As such, universal values are counterproductive to the achievement of UNESCO's GCE.

To analyse the texts, I used Fairclough's (2003) concept of relationships of equivalence and difference. The significance of these relationships lies in their potential to fix meaning within texts. A fixed meaning influences the set of possibilities that exist for constructing meaning from texts. This can influence the thoughts and actions of social agents, and contribute to changes in social identities, such as those of global citizens. Analysis of the texturing of relationships of equivalence and difference shows that UNESCO has instantiated a strict sense of institutional values, termed 
'universal values', with the implication that successful global citizenship is defined by the powerful. Other values are positioned as outdated and invisible, further reinforcing universal values as the only values that make an acceptable global citizen. For GCE to achieve its purposes, the texts must take account of context and incorporate a more diverse conception of values that can increase the possibility that the aims of GCE can be achieved.

First, I discuss the contested nature of GCE and the vague nature of its definitions, which potentially leave GCE open to being co-opted by those in power. I then explore the role of values, adopting the position that values motivate action and are used to evaluate actions deemed worthwhile. I highlight the interplay between education and values, as education promotes, transmits and amplifies values. With values as motivators of action and as the basis on which actions and choices are evaluated as worthwhile, which values are played out through education and how this may influence motivation and action towards global citizenship become vital questions. Following the exploration of values, I present an analysis arguing that universal values potentially become counterproductive to the achievement of UNESCO's GCE. For GCE to achieve its purposes, the texts must take account of context and incorporate a more diverse conception of values that can increase the possibility that the aims of GCE can be achieved.

\section{GCE as a contested concept}

Global citizenship and GCE are terms often heard but rarely clearly defined. Citizenship in national terms, signifying membership of a bounded state, often with associated legal rights, is better understood, but when it comes to the global space, institutions of governance that may afford 'global citizens' similar citizenship status and associated legal rights, such as participating in voting, do not exist (Fraser, 2010). A global citizen is not a citizen in this legal sense, and yet the concept of global citizenship is accompanied by an expectation that citizens will nonetheless participate towards the aim of mutual human well-being and across national borders - at least that is the idea. How one may participate, and towards whose ideals of well-being, are less well defined and tend to rest on concepts of a universal and shared humanity.

While a definition of global citizenship remains contested, there is wide agreement that being a global citizen includes three main elements: a sense of acting for peace and justice, a pluralism to be open to diverse perspectives or a common humanity, and knowledge and action for global problems such as climate change. Barrow (2017: 164) supports the wide acceptance of this definition, summarizing that at its core, global citizenship recognizes a shared humanity.

While the common aims of GCE are widely accepted, the lack of a clear definition has been problematic. Leduc (2013: 394) states that the interpretation of GCE is dependent on the 'point of view and purpose of the user' and Sigauke (2011: 81) argues that its meaning is 'subject to differential interpretations and agendas'. Some of the difficulties in interpreting GCE may also be seen in the many contested concepts within GCE (Oxley and Morris, 2013; Wang and Hoffman, 2016). This is partly why engaging with global citizenship has been described as a 'struggle' (Gaudelli, 2016: 5). This is not surprising when one considers that the multiple conceptions of the words 'global', 'citizenship' and 'education' can raise different and often competing meanings. As Tully (2014: 4) expounds:

When 'globalisation' and 'citizenship' are combined, they not only bring their contested histories of meanings with them, their conjunction brings 
into being a complex new field that raises new questions and elicits new answers concerning the meaning of, and relationship between, global governance and global citizenship. When we enquire into global citizenship therefore, we are already thrown into this remarkably complex inherited field of contested languages, activities, institutions, processes and the environs in which they take place.

Education blurs this further, and is often left unexamined. Gaudelli (2016) reminds us that the pedagogies and processes for engaging learners with content are often assumed, while inordinate attention is paid to what the terms 'global' and 'citizenship' mean. As he says, it is 'as if to say that content/information matters, while the processes or pedagogy for engaging content is simply given' (Gaudelli, 2016: 6).

Efforts to clarify these diverse meanings have been made (Tye, 2014; Tarozzi and Torres, 2016). However, these still raise questions about what it means to educate for GCE in practice. Gaudelli (2016: 7) has stated that educating for global citizenship includes:

1. An aspirational sense of being human as a universal condition coupled with openness to the plurality of peoples and their environs

2. all people have the capacity and access to participate in multiple communities, often simultaneously, at a wide range of scales from local to global and

3. students learning about the world they inhabit and gaining experience and reflective insight to act.

He further states that GCE must be accompanied by common themes 'expressed as desires to live peaceably, justly, sustainably and in robust, engaged communities' (Gaudelli, 2016: 7).

These themes are echoed in UNESCO's (2014a: 15) own conception of GCE:

GCE aims to empower learners to engage and assume active roles, both locally and globally, to face and resolve global challenges and ultimately to become proactive contributors to a more just, peaceful, tolerant, inclusive, secure and sustainable world.

While these descriptions of GCE may constitute the most widely accepted definitions, they are not without their issues. Not only are the terms 'global', 'citizenship' and 'education' vague and contested, but the language in the above definitions is also vague. 'Learning about the world', 'gaining reflective insight to act' and being a 'proactive contributor to a more ... secure world' could mean learning about poverty and deciding to act towards poverty alleviation, or learning about terrorism and deciding to retreat into one's own world due to feeling overwhelmed by the problems. How one should act and be a 'proactive contributor' is also not stated. Should one be autocratic, democratic, individual or collective? What does it mean to be 'open to a plurality of peoples'? Does it mean passively holding an attitude of tolerance, or actively engaging with each other? After all, one can hold attitudes and even emotions indicative of a global citizen, but never do anything to act (Davies, 2006). With meanings left vague and ill-defined, they are left open to being co-opted by those in power to further their own agendas, a 'common strategy' of those in power (Biccum, 2010: 87), and a potential 'blank slate for nation states to inscribe their own political values on their citizenry' (VanderDussen Toukan, 2018: 62).

Due to its position as the lead institution for global work towards the SDGs (UNESCO, 2019a), UNESCO is a dominant voice in GCE and prescribes its own 
meaning to aspects of it, namely 'universal values'. I adopt the position that values motivate action, and that they are used to evaluate actions deemed worthwhile. I will now explore how enacting these values may arguably serve UNESCO's agenda.

\section{Values as motivators and evaluators of action}

Dutt (2009: 86) asserts that 'values are important, as they are the well-spring of human action'. Moreover, Joas (2000: 17) states that 'action orientations ... result from internalised values'. In addition to motivating action, values also play a part in how people evaluate which actions are worthwhile. People's values will lean towards actions that are 'felt and considered to be justified' (Joas, 2000: 17). Values are central to the effectiveness of GCE, which espouses acting towards the benefit of mutual human well-being across national borders. Education is a key site in the interplay between values, the individual and society.

Education promotes, amplifies and transmits values, both within education itself and within wider society (Welzel, 2013; Fives, 2013; Vaughn and Walker, 2012). The individual, motivated by their values towards actions that they deem worthwhile, will subsequently act within society. Society, with a prevailing values emphasis, may also influence an individual's actions towards those considered desirable, influenced perhaps through social pressure to conform or through social confirmation of values seen as desirable (Schwartz, 2006; Welzel, 2013). These values then influence how people are motivated to act as citizens, and how actions as global citizens are confirmed. Values act as social regulators of action. Further, Welzel (2013) asserts that education tends towards emancipation, and that emancipation occurs through social cross-fertilization. The more education there is in a society, the more values will be communicated through social interaction. This also influences those who are less educated, as they adapt their values to keep up with social change: the 'elevator effect' (Welzel, 2013: 110). Where the focus is on universal values, education can potentially be used to influence not just learners but wider society towards the agenda of UNESCO. In promoting a particular set of values that make an appropriate global citizen, other values and ways of doing global citizenship, such as those originating within negotiation at the local level (Tully, 2014), are implied to be inappropriate and unable to produce successful global citizens. This privileges one view at the expense of others. VanderDussen Toukan (2018) suggests that, to avoid this, the contributions of grass-roots efforts in local contexts should be considered before policymakers adopt guidelines from elsewhere.

It is not that universal values are necessarily bad or antisocial. UNESCO's position is to treat values as 'forward looking' to try to predict future troubles and how to remedy them (Bindé, 2004: xv). Further, UNESCO talks of universal values as humanistic values that, in line with its future-orientated approach, have been created by imagining a better alternative to situations of human misery (Spijkers, 2012). Universal values may be well intentioned, and those such as justice, peace and sustainability are normatively considered a common good. In fact, the elevator effect applied to universal values may be positive in nations whose values may not currently align with mutual human well-being. Vaughn and Walker (2012: 497) acknowledge that:

communities might choose educational values that are not to the benefit of all (e.g. girls), so either there needs to be some core of universal values arising from the goal of 'human development', and/or a process that subjects a particular community's or society's reasoning about education to impartial scrutiny. 
Pigozzi (2006: 2) agrees that 'shared values may not always be positive', and supports the promotion of universal values. Tarozzi and Torres (2016) agree that universal values have a place within GCE, and they also support the inclusion of diversity. But UNESCO is critiqued as a vehicle for Western powers (Biccum, 2010). If particular identities as successful global citizens are confirmed through universal values, this potentially serves the agenda of UNESCO and is also in danger of considering inferior anyone not currently aligned with the organization's idea of success. Attempts to bring others up to that standard risk reproducing the worst of Western dominance. Postcolonial approaches to GCE hold promise through the development of a 'critical consciousness', which can help to address power imbalances (Howard et al., 2018: 502), but to be successful, these would 'require avoiding essentialist attitudes that seek to develop identities through the unification of values' (Howard et al., 2018: 512). In other words, universal values are unlikely to redress power imbalances, and instead are likely to further instantiate UNESCO's view. Through the analysis that follows, I argue that UNESCO's universal values are counterproductive to the achievement of GCE.

\section{Method}

I analysed eight core documents representing UNESCO's key messages about GCE. These were:

- 1st Global Capacity-Building Workshop on GCED: 19 June-2 July 2016, Seoul and Gwangju, Republic of Korea: Final report (UNESCO, 2016a)

- Final Report: Second UNESCO Forum on Global Citizenship Education: Building peaceful and sustainable societies, UNESCO Paris, 28-30 January 2015. (UNESCO, 2015b)

- Global Citizenship Education: Preparing learners for the challenges of the 21st century (UNESCO, 2014a)

- 'Priority \#3: Foster global citizenship' (UNESCO, 2016b)

- 'Global Education First Initiative: The UN Secretary-General's global initiative on education' (UNESCO, n.d.a)

- 'Outcome document of the Technical Consultation on Global Citizenship Education: Global citizenship education: An emerging perspective' (UNESCO, 2013)

- Global Citizenship Education: Topics and learning objectives (UNESCO, 2015a)

- 'The ABCs of global citizenship education' (UNESCO, n.d.b).

These documents were available on the main UNESCO GCE website, that of its precursor the Global Education First Initiative (GEFI) and the website found through the hyperlink for GCE on the GEFI page, since this also focused on GCE. They are all published by UNESCO. There were four documents on the website that were excluded from analysis. This is because they were either not focused on GCE (UNESCO, 2014b), did not mention values (GEFI, n.d.) or could not be said to represent the views of UNESCO (Tawil, 2013).

The eight documents are situated within a wide history of consultation, and reflect the specific goal for GCE ratified at the World Economic Forum in Incheon in 2015 (WEF, 2015). While UNESCO owns the copyright of the documents, a disclaimer states that they do not commit themselves to the opinions of the authors. However, UNESCO (2019b: n.p.) states that GCE is 'UNESCO's response' to global challenges, and that it is a 'strategic area of UNESCO's education sector programme', and further that the concepts of GCE were 'developed by UNESCO'. In so doing they communicate 
ownership of GCE. Further, given that UNESCO owns the copyright, and that UNESCO's official documents hold weight when key messages concerning GCE are sought, and given that authorship is not attributed elsewhere, I have treated the documents as reflecting UNESCO's position. This approach was also followed by Wickens and Sandlin (2007), who found similar disclaimer statements on UNESCO documents within their study on literacy education. Furthermore, VanderDussen Toukan (2018: 56), in her analysis of three UNESCO texts, comments that such a discourse analysis can help to 'better understand the discursive environment that UNESCO expects ministries and educators to navigate across the diverse range of its member states', situating the discourse within UNESCO.

I have analysed the position of values using critical discourse analysis (CDA). To contribute methodologically to an area that is under-researched (Rogers et al., 2016), I have also conducted a multimodal analysis so that all the resources available within the text for constructing meaning can be considered. Applying a multimodal approach resists the hegemony of the few dominant voices in CDA by 'attending to the dynamics between meaning making resources' (Rogers et al., 2016: 1215) and not relying on one method. This overcomes a limitation of traditional CDA, which only focuses on language. My approach combines methods from three areas: linguistic (Fairclough, 2003), visual grammar (Kress and Van Leeuwen, 2006) and logical (Ledin and Machin, 2015), which goes beyond complementing the linguistic with the photographic, for example. CDA is generally concerned with power relations between authors and receivers, but through considering how the logical may make discourse even more resistant to challenge, a deeper understanding of how the powerful may control discourse as a tool of social regulation is gained. This adds nuance to CDA, enhancing its contribution to social analysis.

I analysed relationships of equivalence and difference within the texts (Fairclough, 2003). Structuring values in relations of equivalence has the effect of reducing the difference between values and other items. Items are of 'equal status' (Matthiessen et al., 2010: 132) and difference is subverted (Lapping, 2008). This foregrounds what is common and can make difference invisible (Khoja-Moolji, 2016). However, because difference is subverted, this can come at the expense of identity (Lowrie, 2007). The particular is removed, creating space for the universal (in this case, universal values) to dominate. Semantically, I analysed equivalence through 'additive relations' (Martin and Rose, 2007: 118), where items are considered to have equal status. Additive relations included being positioned in lists (Morrell and Hewison, 2013; Fairclough, 2003) and use of the conjunction 'and' (Martin and Rose, 2007). I also analysed whether one item in the sentence (values) may be dependent on another. Items are equivalent if they are not dependent. This means that the order of clauses can be reversed without changing the meaning or logic of the sentence (Martin and Rose, 2007). Structuring values in relationships of difference also communicates meaning, because these relationships define what values are not. I analysed relations of difference through seeing where values were in contrast, in opposition to, or as opposite to other items, which highlights rather than reduces difference (Fairclough, 2003; Feldman et al., 2004). By highlighting difference, the particular is foregrounded, which could help to resist the dominance of the universal and give room to identity and context.

I analysed whole documents using both a manual search for the word 'values' in graphic images and an analysis of the concordance of the word 'values' in the text via the computer programme AntConc (www.laurenceanthony.net/software/antconc/). A manual search was necessary because AntConc did not account for mentions of values in diagrams or pictures. Each mention of the word 'values' was then viewed in 
its context within AntConc, and the full sentence was placed into Excel spreadsheet. De Felice and Janesick (2015) state that Excel is an appropriate tool for making sense of text. In Excel, I first made general observations on the context for each statement to ensure interpretation of the use of the word 'values' was accurate. I then analysed the statements individually to see if and how values were placed in relations of equivalence and difference. Since this is a multimodal analysis, I then analysed each sentence in relation to its visual grammar (Kress and Van Leeuwen, 2006) and sense of logic (Ledin and Machin, 2015).

Equivalence and difference separately can provide insight, but it is the texturing of equivalence and difference together that can illustrate how meaning is fixed and what possibilities for constructing meaning exist for social actors. This is because fixing meaning can contribute to 'new configurations of discourses' that can also 'produce changes in knowledge, social relations, and social identities' (Fairclough et al., 2002: 8). In the words of Biccum (2010: 16), 'how the discourse is constructed informs the horizon of possibilities of what can become'.

\section{Analysis}

\section{Relationships of equivalence}

Out of 128 sentences that mention 'values' with other items, values are placed in relationships of equivalence 100 times and in relationships of difference 11 times. Remaining statements either do not meet the criteria for assessing equivalence and difference, or values are mentioned alone.

When analysing the items that were in relationships of equivalence with values, these could be grouped under two headings: 'Reducing difference and privileging commonality' and 'Being disconnected from social reality'. Each theme will now be discussed.

\section{Theme 1: Reducing difference and privileging commonality}

My analysis revealed that there are 45 items structured as equivalent to 'values' (see Table 1); for example, in sentences such as: 'GCE aims to be transformative, building the knowledge, skills, values and attitudes to enable learners to contribute to a more inclusive, just and peaceful world' (UNESCO, 2015a: 15), equivalence is measured where values are placed in a list (Morell and Hewison, 2013; Fairclough, 2003) and the conjunction 'and' is used with the items not dependent on each other (Martin and Rose, 2007) (see Table 1).

The most common items equivalent to values are skills, attitudes and knowledge. Which skills, attitudes or knowledge is left undefined. Their meaning is vague. In fact, all items in Table 1 are arguably vague in meaning. Placing values in relationships of equivalence subverts the difference between values and other items (Lapping, 2008). Placing values in relationships of equivalence with so many different items dilutes that difference to the point of eliminating difference almost completely, arguably leaving nothing unique about values. This suggests that equivalence has been privileged to the extent that difference is almost completely gone (Lapping, 2008). Without uniqueness, values can be applied regardless of context, and are then considered 'universal values'. For example, 'In conflict and in post-conflict settings, GCE can support nationbuilding, social cohesion and positive values in children and youth' (UNESCO, 2014a: 16). Notwithstanding the controversial nature of nation building, seen as a vehicle to pursue national self-interest, rather than assisting nations towards competent self- 
governance (Smith and Shrimpton, 2011), values are linked to the national and social. In addition to being linked to the national and social, elsewhere in the documents, universal values are placed as equivalent to both local context and global issues. Taken together, placing values as equivalent to the global, local, national and social reduces the difference between them and assists in instantiating the universal nature of values, applied everywhere.

\section{Table 1: List of items in equivalence with values in order of frequency}

\begin{tabular}{|c|c|c|c|c|c|}
\hline 1 & attitudes & 16 & $\begin{array}{l}\text { critical thinking } \\
\text { (including critical } \\
\text { empowerment) }\end{array}$ & 31 & $\begin{array}{l}\text { awareness of living } \\
\text { together }\end{array}$ \\
\hline 2 & $\begin{array}{l}\text { skills (Including soft, } \\
\text { communication, social } \\
\text { and emotional) }\end{array}$ & 17 & factors & 32 & practical capacities \\
\hline 3 & knowledge & 18 & perceptions & 33 & common humanity \\
\hline 4 & behaviour & 19 & world views & 34 & $\begin{array}{l}\text { social context (including } \\
\text { structure, cohesion) }\end{array}$ \\
\hline 5 & $\begin{array}{l}\text { beliefs and belief } \\
\text { systems }\end{array}$ & 20 & ethics & 35 & $\begin{array}{l}\text { role of young people/ } \\
\text { support for youth }\end{array}$ \\
\hline 6 & views & 21 & transformation & 36 & global issues \\
\hline 7 & $\begin{array}{l}\text { acceptance of universal } \\
\text { human rights }\end{array}$ & 22 & respect & 37 & global identity \\
\hline 8 & $\begin{array}{l}\text { principles (including of } \\
\text { communication) }\end{array}$ & 23 & responsibilities & 38 & practices \\
\hline 9 & ideas & 24 & teamwork & 39 & emerging issues \\
\hline 10 & goals & 25 & achievements & 40 & spirit \\
\hline 11 & competencies & 26 & impact on community & 41 & holism \\
\hline 12 & identities & 27 & sharing & 42 & nation building \\
\hline 13 & diversity of people & 28 & dialogue & 43 & $\begin{array}{l}\text { willingness to help } \\
\text { others }\end{array}$ \\
\hline 14 & culture & 29 & equality & 44 & $\begin{array}{l}\text { mainstreaming } \\
\text { education }\end{array}$ \\
\hline 15 & ways of life & 30 & $\begin{array}{l}\text { sustainable } \\
\text { development }\end{array}$ & 45 & interests \\
\hline
\end{tabular}

However, difference is recognized in the influence of national policies, cultural norms and values - these are not ignored - and UNESCO (2014a: 22) asserts that these should be considered by educators and learners for GCE to be effective, perhaps indicating that the universal has not come to dominate completely: 'training on participatory and transformative pedagogical practices that ... recognize cultural norms, national policies and international frameworks that impact on the formation of values'. But the response is passive: the impact is only recognized. UNESCO then articulates that it is the 'core values of GCE' that policy and curricula should include, suggesting that, while the aforementioned difference is recognized, universal values should predominate: 'While the modality of delivery may not be a major issue, the core values of GCE must be reflected in and supported by education policy and the curriculum in order to deliver GCE effectively' (UNESCO, n.d b: 4, Question 10). Equivalence is privileged over a recognition of difference. The universal nature 
of values, applied regardless of context, dominates. This can be seen as a way of minimizing or avoiding national and local complexities in favour of a universal view.

\section{Theme 2: Disconnected from social reality}

Privileging commonality and the universal offers an appearance of unity. Laclau and Mouffe (2001) assert that an appearance of unity occurs when items are abstract (the 45 equivalent items in Table 1 are abstract), but that this disconnects them from their underlying social reality. For example, 'belief systems' as an abstract item does not acknowledge the reality of working out how to achieve harmonious interactions between different religious groups. 'Values' as an abstract item does not acknowledge the challenges of dealing with conflicting values. Values become disconnected from their social reality. The effects of privileging commonality and making difference invisible can be seen in the example of the Sankofa Elite School in Ghana. Howard et al. (2018) report that this school's approach to GCE forbids students to discuss their differences, in the belief that focusing on what they have in common is the best way to achieve the idealized version of a global citizen that is defined by Western ideals. However, this denies the social realties within which students live, and has resulted in students becoming dissociated from their unique national identities.

UNESCO (2015b: 7), however, does acknowledge a disconnect between universal values and the reality of their implementation in social life, viewing it largely as a problem with policy:

During the Forum, it was acknowledged that often there is a gap between teacher policies and practice. This is due to the lack of conceptual clarity in policy formulation, lack of coherence in policy implementation and lack of appropriate support for teachers.

But UNESCO's solution to the problem is more universal values: 'While the modality of delivery may not be a major issue, the core values of GCE must be reflected in and supported by education policy and the curriculum in order to deliver GCE effectively' (UNESCO, n.d.b: 4, Question 10). However, because values are abstract, this can only contribute to the problem because they are disconnected from social reality. An implication of this concerns whether values can achieve the purposes (or motivate and evaluate action towards them) within GCE that they have been set. These purposes are to:

- 'resolve interconnected challenges of the 21 st century and establish peaceful and sustainable societies' (UNESCO, 2015b: 10, 11)

- 'secure a just and sustainable world' (UNESCO, 2014a: 7)

- 'secure a world that is more just, peaceful, tolerant, inclusive, secure and sustainable' (UNESCO, 2014a: 9)

- 'facilitate international cooperation and promote social transformation' (UNESCO, 2014a: 9)

- 'build a more just, peaceful and sustainable world' (UNESCO, 2014a: blurb)

- 'promote social transformation and build cooperation between nations' (UNESCO, 2014a: blurb)

- 'contribute to a more inclusive, just and peaceful world' (UNESCO, 2015a: 15)

- 'live together peacefully' (UNESCO, 2015a: 37).

Values are to contribute to achieving global peace, sustainability, justice, tolerance, inclusion and security. Values are also to contribute to enabling resolution of challenge, facilitating international cooperation and achieving a measure of social transformation. 
The use of verbs positions values as active - they are to have an effect and achieve. Yet these purposes are themselves abstract. They are 'vague yet powerful social ideals that cannot be clearly defined but are normatively charged' (Laclau and Mouffe, in Renner, 2014: 267). Acknowledging the disconnect between universal values and their implementation in social life is subsumed within more abstract ideals. Universal values remain disconnected from social reality and cannot achieve the purposes for which they are set.

The purposes of GCE as social ideals privilege an 'idealised future' (Mowles, 2007: 407). Privileging an idealized future may not be problematic in itself - this is, after all, the mission of UNESCO, which describes its purpose as 'building peace in the minds of men and women' (https://en.unesco.org), and which began its work, and established values, based on imagining a future better than human misery (Spikjers, 2012). But promoting abstract ideals can also be a way of avoiding the challenge and complexities involved in everyday reality (Mowles, 2007). An appearance of unity is maintained, but this is only surface level. Positioning values in the abstract, arguably as ways of avoiding difference and social reality, is counterproductive to achieving the purposes of GCE, resulting in a position on values that is self-defeating.

\section{Relationships of difference}

Relationships of difference include putting values in contrast, in opposition or as opposite to other things, which, in contrast to relations of equivalence, highlights rather than reduces that difference (Fairclough, 2003; Feldman et al., 2004). Analysis of relationships of difference reveal values as doing something 'new'. UNESCO implies that any prior conception of values is old, suggesting they are not fit for modern times. This leaves values open for a new definition, creating space for UNESCO to ascribe its own meaning to values. Relationships of difference create this space in three ways: by implicitly contrasting with an 'old' education, by placing values in opposition to cognitive skills and by situating values as the solution to unresolved global challenges. In so doing, values prior to GCE are positioned as invisible and outdated, and their shortcomings are seen as the cause of global problems. Ultimately, relationships of difference do not challenge the privileged commonality of equivalence, and instead reinforce it. This will now be explored.

\section{A 'new' education: Values as outdated}

Values are placed in a relationship of difference to what UNESCO implies is the old way of doing education. In discussing the increasing importance of GCE in today's world, previous UNESCO Director-General, Irina Bokova, stated:

We need new skills for new times - to foster greater respect and understanding between cultures, to give learners tools to make the most of diversity, to develop new values and behaviours of solidarity and responsibility, to harness the energy of young women and men for the benefit of all. (UNESCO, 2015b: 5)

Stating that the world is in 'new times' that require 'new values' positions GCE and values as something new in contrast with something 'old'. GCE and its values are in a relationship of difference to 'old' styles of education, creating space for UNESCO to define what is needed for these new times. There is space for UNESCO to ascribe its own meaning to 'values'. 
From a multimodal perspective, in the context of the original document, UNESCO provides further emphasis through the positioning of this quotation in a box. Kress and Van Leeuwen (2006) consider this to be an element of framing, giving the quotation salience. The eye is drawn to the box, and the quotation is also in italics, adding additional emphasis. Not only does UNESCO pave the way for something new through contrasting it with the old through relationships of difference, it adds importance to the message through the use of visual grammar.

\section{Knowledge and cognitive skills: Values as invisible}

In addition to being placed in a relationship of difference to an 'old' education, values are further placed in relationships of difference to knowledge, reading, writing, counting and cognitive skills as these two quotes illustrate: 'It is not enough for education to produce individuals who can read, write and count. Education must be transformative and bring shared values to life' (UNESCO, 2016b: n.p.); 'It [GCE] also acknowledges the role of education in moving beyond the development of knowledge and cognitive skills to build values, soft skills and attitudes among learners that can facilitate international cooperation and promote social transformation' (UNESCO, 2014a: 9).

In moving beyond transmission of knowledge and cognitive skills, UNESCO implicitly positions them as part of the old education. GCE has new goals - the development of values for the purposes of international cooperation and social transformation. This does not suggest that cognitive skills and knowledge are not to be included in the new education, but alone they are not enough.

Values are only mentioned as part of the new educational goals. At no point are values mentioned as part of the old education, even though 'old' values, in particular those stemming from human rights, have formed part of UNESCO's educational efforts for decades. Previous values are rendered invisible. This further allows UNESCO to position values as new and ascribe their own meaning - there is, after all, apparently no prior or alternative meaning of values to contend with.

\section{Values as the answer to global challenges}

In addition to situating values as part of a 'new' education and rendering prior values invisible, values are portrayed as the solution to unresolved global challenges. This implies that universal values can achieve resolution where previous attempts have failed, additionally suggesting something 'new' will occur. For example, values are implied to be an answer to school violence:

The values of peace, human rights, respect, cultural diversity and justice are often not embodied in the ethos of schools. Instead of empowering students to learn and thrive, schools often replicate social inequalities and reinforce social pathologies by tolerating bullying and genderbased violence and subjecting children to physical and psychological punishment. (UNESCO, 2016b: n.p.)

This statement implies that an absence of values in the ethos of a school bears some responsibility for school violence. Bullying, physical and psychological harm are aspects of school violence, described as a 'global problem' that impacts upon educational outcomes, quality and the physical, emotional and mental health of students (UNESCO, 2017). Values are implicitly linked to empowerment and thriving, opposites of the impacts of school violence, and are posited as the solution to this 
global challenge. Values are explicitly named here. These particular values - defined by UNESCO - are the ones that will bring the solution.

The multimodal analysis also shows a relationship of difference. As has been seen in the quotation from Irina Bokova (UNESCO, 2015b: 5), and is also seen in Figure 1, placing elements in a box frames them as standing out from the text, and gives them salience, drawing the eye.

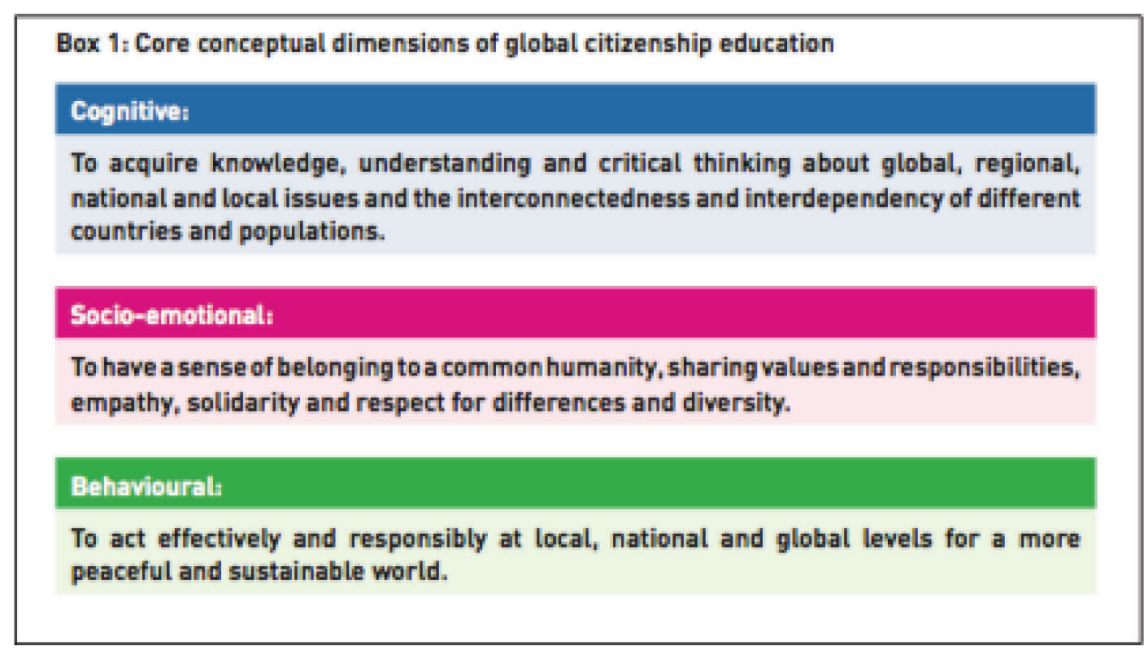

Figure 1: Framing devices contribute to relationships of equivalence and difference Source: UNESCO (2015: 15)

In addition to the use of a box, the use of different colours for each dimension (blue for cognitive, pink for socio-emotional and green for behavioural) additionally draws the eye. This distracts from a linear reading of the text and contributes to scan reading - taking in the salience of this image first and not reading the detail of the text (Lazard and Atkinson, 2015; Kress and Van Leeuwen, 2006). 'Values' is mentioned once as part of the socio-emotional dimension. Separating the dimensions makes them into discrete units, potentially obscuring links between them that may be useful for professional practice (Ledin and Machin, 2015). This sets up a relation of difference between values and other dimensions of learning, suggesting that values do not have a place in cognitive or behavioural learning of global citizenship. This is emphasized by repeating the domains in bullet points in a separate section (UNESCO, 2015a: 15). Further, the image is placed on the left side of a double page spread and its 'information value', which assigns significance to the placement of a visual element (Kress and Van Leeuwen, 2006: 177), suggests that the separation of values in this way is a given, an unquestioned norm. While the text does state that the domains are mutually reinforcing, it is the visual that carries more persuasive impact than language (Lazard and Atkinson, 2015). The use of bullet points and separation into discrete units contributes a sense of logic to the text, which in addition to taking precedence over the language, also adds legitimacy to the discourse and makes it more resistant to challenge (Ledin and Machin, 2015). The multimodal analysis reifies 'values' and emphasizes relationships of difference that reinforce the suggestion that it is UNESCO's universal values that are the only values that can make a successful global citizen. With universal values as abstract and divorced from local contexts, this potentially reduces the effectiveness of UNESCO's approach to GCE.

The use of multimodal analysis has exemplified the contribution it can make to overcoming the dominant voices within critical discourse analysis, which arguably focus 
on language. Without it, the interpretation of texts would have been swayed towards the language, missing the greater persuasive aspects of the visual. Taken together, the multimodal analysis affords a more complete analysis of texts by considering all the elements that communicate meaning.

\section{Summary}

Values are placed in relationships of equivalence with many other items, effectively diluting difference to the extent that there is almost nothing unique about values they have been emptied of meaning. This has created space for UNESCO to fill 'values' with their own meaning. My analysis of relationships of difference has reinforced this. UNESCO arguably positions universal values as new, and any prior values as outdated, invisible and their lack potentially the cause of global issues. Through creating space for something new and subverting uniqueness almost completely, a conception of values has been presented that can be applied in any context. Values can be considered universal.

As discussed, values can act as social regulators of people's actions, such that they serve the agenda of the powerful. In this case, having defined a particular set of universal values that have achieved social dominance, people are potentially socialized to think and act in ways that serve UNESCO's agenda. This then arguably furthers Western dominance and, with universal values suggested as the only values that can achieve success as a global citizen, carries the danger of attempting to bring up to standard those not considered as meeting UNESCO's ideals. GCE becomes not a vehicle for mutual human well-being as espoused, but one for the social regulation of action and the potential moulding of the 'other' as citizens in UNESCO's image.

I have also shown that through privileging what is common, universal values are abstract, avoiding the complexities of social reality. UNESCO may possibly 'discover commonality' as a way to move forwards in their global work in the face of complex differences between cultures and nations (Khoja-Moolji, 2016: 761), but while commonality may give an appearance of unity, this is only surface level. Considering that GCE promotes the enacting of values, their disconnection from social reality has resulted in universal values that are self-defeating because they arguably cannot achieve their aims. In practice, being abstracted from social reality has led to citizenship education being resisted by local communities, who perceive that universal values are being imposed rather than chosen, and are not relevant to them (Koya, 2010), reinforcing the potentially self-defeating nature of universal values. A potential benefit can be found in taking account of evidence from the World Values Survey (www.worldvaluessurvey.org/wvs.jsp) that values exist in distinct cultural zones around the world, and that values do not always remain static. Applying values universally and indiscriminately without consideration of context is likely to continue to lead to resistance in different cultural zones, as universal values are perceived to lack relevance, arguably reducing the effectiveness of UNESCO's GCE.

\section{Implications}

For values to contribute to making GCE more effective, it is important for UNESCO to take account of context and incorporate a more diverse conception of values. This can increase the possibility that the aims of GCE can be achieved, but in ways more suited to local contexts. Local realities and values are mentioned in a recent publication (UNESCO, 2018), but they are seen as useful only in so far as they support UNESCO's 
concept of GCE. If they do not, they are not recognized as legitimate 'entry points' for GCE, potentially reinforcing UNESCO's view of what makes a successful global citizen. As stated a possible way forward would be to acknowledge evidence from the World Values Survey (www.worldvaluessurvey.org/wvs.jsp) that values exist in distinct cultural zones, and recognize that a universal approach is counterproductive. There may still be a place for promoting social ideals such as peace, justice and sustainability, which can provide aspiration, but perhaps not as values. Because values act as regulators of social action such that people serve power, because values act as motivators for and evaluators of action deemed worthwhile, and because education elevates those without education towards emphasized values of a society, values are arguably too important not to be focused on the everyday realities faced by communities.

One group of values that may potentially aid this diverse conception is that of emancipative values (Welzel, 2013). Emancipative values include choice, voice, equality and autonomy. If these values were to be a part of the textual discourse that forms the set of possibilities for constructing the meaning of GCE, then that education may arguably consider how social ideals can be interpreted in light of individual and local context. Biccum's (2010) horizon of possibilities of what may become expands. Further research is needed to analyse the potential impact of including emancipative values, but nonetheless it provides a start in considering how GCE, as espoused by UNESCO, can be used not as a potential vehicle for the continued dominance of Western powers, but one for the promotion of genuine mutual human well-being.

\section{Notes on the contributor}

Jenny Hatley is Lecturer in education at the University of Worcester, UK. Her interest in global citizenship began when she worked as an aid worker, managing education projects in areas of post-conflict and natural disaster. For many years, Jenny continued to advocate for global learning in UK primary schools, and she now pursues her interest through research and teaching in higher education.

\section{References}

Barrow, E. (2017) 'No global citizenship? Re-envisioning global citizenship education in times of growing nationalism'. High School Journal, 100 (3), 163-5.

Biccum, A. (2010) Global Citizenship and the Legacy of Empire: Marketing development. London: Routledge.

Bindé, J. (ed.) (2004) The Future of Values: 21st-century talks. New York: Berghahn Books and UNESCO.

Davies, L. (2006) 'Global citizenship: Abstraction or framework for action?'. Educational Review, 58 (1), 5-25.

De Felice, D. and Janesick, V.J. (2015) 'Understanding the marriage of technology and phenomenological research: From design to analysis'. Qualitative Report, 20 (10), 1576-93.

Dutt, S. (2009) 'Striving to promote shared values: UNESCO in the troubled world of the twenty-first century'. India Quarterly: A Journal of International Affairs, 65 (1), 83-95.

Fairclough, N. (2003) Analysing Discourse: Textual analysis for social research. London: Routledge.

Fairclough, N., Jessop, B. and Sayer, A. (2002) 'Critical realism and semiosis'. Alethia, 5 (1), 2-10.

Feldman, M.S., Sköldberg, K., Brown, R.N. and Horner, D. (2004) 'Making sense of stories: A rhetorical approach to narrative analysis'. Journal of Public Administration Research and Theory, 14 (2), 147-70.

Fives, A. (2013) 'Non-coercive promotion of values in civic education for democracy'. Philosophy and Social Criticism, 39 (6), 577-90.

Fraser, N. (2010) Scales of Justice: Reimagining political space in a globalizing world. New York: Columbia University Press.

Gaudelli, W. (2016) Global Citizenship Education: Everyday transcendence. New York: Routledge. 
GEFI (Global Education First Initiative) (n.d.) Using the Transformative Power of Education to build a better future for all. Paris: UNESCO.

Howard, A., Dickert, P., Owusu, G. and Riley, D. (2018) 'In service of the Western world: Global citizenship education within a Ghanaian elite context'. British Journal of Educational Studies, 66 (4), 497-514.

Joas, H. (2000) The Genesis of Values. Cambridge: Polity Press.

Khoja-Moolji, S. (2016) 'Doing the "work of hearing": Girls' voices in transnational educational development campaigns'. Compare: A Journal of Comparative and International Education, 46 (5), 745-63.

Koya, C.F. (2010) 'Civics education in Fiji: Contradiction or "pedagogy of hope"?'. In Kennedy, K.J., Lee, W.O. and Grossman, D.L. (eds) Citizenship Pedagogies in Asia and the Pacific. Hong Kong: Comparative Education Research Centre, 245-68.

Kress, G. and Van Leeuwen, T. (2006) Reading Images: The grammar of visual design. 2nd ed. London: Routledge.

Laclau, E. and Mouffe, C. (2001) Hegemony and Socialist Strategy: Towards a radical democratic politics. 2nd ed. London: Verso.

Lapping, C. (2008) 'The ethics of interpretation: The signifying chain from field to analysis'. Discourse: Studies in the Cultural Politics of Education, 29 (1), 69-83.

Lazard, A. and Atkinson, L. (2015) 'Putting environmental infographics center stage: The role of visuals at the Elaboration Likelihood Model's critical point of persuasion'. Science Communication, 37 (1), 6-33.

Ledin, P. and Machin, D. (2015) 'How lists, bullet points and tables recontextualize social practice: A multimodal study of management language in Swedish universities'. Critical Discourse Studies, 12 (4), 463-81.

Leduc, R. (2013) 'Global citizenship instruction through active participation: What is being learned about global citizenship?'. Educational Forum, 77 (4), 394-406.

Lowrie, A. (2007) 'Branding higher education: Equivalence and difference in developing identity'. Journal of Business Research, 60 (9), 990-9.

Martin, J.R. and Rose, D. (2007) Working with Discourse: Meaning beyond the clause. 2nd ed. London: Continuum.

Matthiessen, C.M.I.M., Teruya, K. and Lam, M. (2010) Key Terms in Systemic Functional Linguistics. London: Continuum.

Morrell, K. and Hewison, A. (2013) 'Rhetoric in policy texts: The role of enthymeme in Darzi's review of the NHS'. Policy \& Politics, 41 (1), 59-79.

Mowles, C. (2007) 'Promises of transformation: Just how different are international development NGOs?'. Journal of International Development, 19 (3), 401-11.

Oxley, L. and Morris, P. (2013) 'Global citizenship: A typology for distinguishing its multiple conceptions'. British Journal of Educational Studies, 61 (3), 301-25.

Pigozzi, M.J. (2006) 'A UNESCO view of global citizenship education'. Educational Review, 58 (1), $1-4$.

Renner, J. (2014) 'The local roots of the global politics of reconciliation: The articulation of "reconciliation" as an empty universal in the South African transition to democracy'. Millennium: Journal of International Studies, 42 (2), 263-85.

Rogers, R., Schaenen, I., Schott, C., O'Brien, K., Trigos-Carrillo, L., Starkey, K. and Carter Chasteen, C. (2016) 'Critical discourse analysis in education: A review of the literature, 2004 to 2012'. Review of Educational Research, 86 (4), 1192-226.

Schwartz, S.H. (2006) 'A theory of cultural value orientations: Explication and applications'. Comparative Sociology, 5 (2-3), 137-82.

Sigauke, A.T. (2011) 'Citizenship and citizenship education: A critical discourse analysis of the Zimbabwe Presidential Commission Report'. Education, Citizenship and Social Justice, $6(1), 69-86$.

Smith, M.G. and Shrimpton, R. (2011) 'Nation-building interventions and national security: An Australian perspective'. Global Dialogue, 13 (1), 126-39.

Spijkers, O. (2012) 'Global values in the United Nations Charter'. Netherlands International Law Review, 59 (3), 361-97.

Tarozzi, M. and Torres, C.A. (2016) Global Citizenship Education and the Crises of Multiculturalism: Comparative perspectives. London: Bloomsbury Academic.

Tawil, S. (2013) Education for "Global Citizenship": A framework for discussion (ERF Working Paper 7). Paris: UNESCO Education Research and Foresight. Online. https://tinyurl.com/yxlfvthw (accessed 10 March 2019). 
Tully, J. (2014) On Global Citizenship: James Tully in dialogue. London: Bloomsbury Academic.

Tye, K.A. (2014) 'Global education: A worldwide movement - An update'. Policy Futures in Education, 12 (7), 855-71.

UNESCO (United Nations Educational, Scientific and Cultural Organization) (n.d.a) 'Global Education First Initiative: The UN Secretary-General's global initiative on education'. Online. www.unesco.org/new/en/gefi/home/ (accessed 10 March 2019).

UNESCO (United Nations Educational, Scientific and Cultural Organization) (n.d.b) 'The ABCs of global citizenship education'. Online. https://tinyurl.com/y53kd35w (accessed 10 March 2019).

UNESCO (United Nations Educational, Scientific and Cultural Organization) (2013) 'Outcome document of the Technical Consultation on Global Citizenship Education: Global citizenship education: An emerging perspective'. Online. https://tinyurl.com/yxq523dw (accessed 10 March 2019).

UNESCO (United Nations Educational, Scientific and Cultural Organization) (2014a) Global Citizenship Education: Preparing learners for the challenges of the 21st century. Paris: United Nations Educational, Scientific and Cultural Organization. Online. https://tinyurl.com/y6c5t2vs (accessed 10 March 2019).

UNESCO (United Nations Educational, Scientific and Cultural Organization) (2014b) Learning to Live Together: Education policies and realities in the Asia-Pacific. Paris: United Nations Educational, Scientific and Cultural Organization. Online. https://tinyurl.com/y4y4d8c7 (accessed 10 March 2019).

UNESCO (United Nations Educational, Scientific and Cultural Organization) (2015a) Global Citizenship Education: Topics and learning objectives. Paris: United Nations Educational, Scientific and Cultural Organization. Online. https://tinyurl.com/yxojzfmf (accessed 10 March 2019).

UNESCO (United Nations Educational, Scientific and Cultural Organization) (2015b) Final Report: Second UNESCO Forum on Global Citizenship Education: Building peaceful and sustainable societies, UNESCO Paris, 28-30 January 2015. Paris: United Nations Educational, Scientific and Cultural Organization. Online. https://tinyurl.com/y3k2mm39 (accessed 10 March 2019).

UNESCO (United Nations Educational, Scientific and Cultural Organization) (2016a) 1st Global Capacity-Building Workshop on GCED: 19 June-2 July 2016, Seoul and Gwangju, Republic of Korea: Final report. Seoul: Asia-Pacific Centre of Education for International Understanding. Online. https://tinyurl.com/yxj674rz (accessed 10 March 2019).

UNESCO (United Nations Educational, Scientific and Cultural Organization) (2016b) 'Priority \#3: Foster global citizenship'. Online. www.unesco.org/new/en/gefi/priorities/global-citizenship/ (accessed 31 August 2017).

UNESCO (United Nations Educational, Scientific and Cultural Organization) (2017) School Violence and Bullying: Global status report. Paris: United Nations Educational, Scientific and Cultural Organization. Online. https://tinyurl.com/yy4j6vos (accessed 10 March 2019).

UNESCO (United Nations Educational, Scientific and Cultural Organization) (2018) Global Citizenship Education: Taking it local. Paris: United Nations Educational, Scientific and Cultural Organization. Online. https://tinyurl.com/yxrkkkj7 (accessed 10 March 2019).

UNESCO (United Nations Educational, Scientific and Cultural Organization) (2019a) 'Education transforms lives'. Online. https://en.unesco.org/themes/education (accessed 13 April 2019).

UNESCO (United Nations Educational, Scientific and Cultural Organization) (2019b) 'Global citizenship education'. Online. https://en.unesco.org/themes/gced (accessed 27 January 2019).

VanderDussen Toukan, E. (2018) 'Educating citizens of "the global": Mapping textual constructs of UNESCO's global citizenship education 2012-2015'. Education, Citizenship and Social Justice, $13(1), 51-64$.

Vaughan, R. and Walker, M. (2012) 'Capabilities, values and education policy'. Journal of Human Development and Capabilities, 13 (3), 495-512.

Wang, C. and Hoffman, D.M. (2016) 'Are we the world? A critical reflection on selfhood in US global citizenship education'. Education Policy Analysis Archives, 24 (56), 1-18.

WEF (2015) Education 2030 Incheon Declaration and Framework for Action: Towards inclusive and equitable quality education and lifelong learning for all. Paris: United Nations Educational, Scientific and Cultural Organization. Online. https://tinyurl.com/zvdewud (accessed 10 March 2019).

Welzel, C. (2013) Freedom Rising: Human empowerment and the quest for emancipation. New York: Cambridge University Press.

Wickens, C.M. and Sandlin, J.A. (2007) 'Literacy for what? Literacy for whom? The politics of literacy education and neocolonialism in UNESCO- and World Bank-sponsored literacy programs'. Adult Education Quarterly, 57 (4), 275-92. 